\title{
KINETICS OF MN-BASED SORBENTS FOR HOT COAL GAS DESULFURIZATION
}

\author{
Semi-Annual Technical Report \\ Reporting Period: December15, 1996 - March15, 1997 \\ Author: M.T. Hepworth \\ Report Issue Date: March, 1997 \\ DE- FG22-94PC94212 \\ University of Minnesota \\ Department of Civil Engineering \\ 500 Pillsbury Dr. S.E. \\ Minneapolis, MN 55435-0220
}




\section{Disclaimer:}

This report was prepared as an account of work sponsored by an agency of the United States Government. Neither the United States Government nor any agency thereof, nor any of their employees, makes any warranty, express or implied, or assumes any legal liability or responsibility for the accuracy, completeness, or usefulness of any information, apparatus, product, or process disclosed, or represents that its use would not infringe privately owned rights. Reference herein to any specific commercial product, process, or service by trade name, trademark, manufacturer, or otherwise does not necessarily constitute or imply its endorsement, recommendation, or favoring by the United States Government or any agency thereof. The views and opinions of authors expressed herein do not necessarily state or reflect those of the United States Government or any agency thereof. 


\begin{abstract}
Manganese-based sorbents have been investigated for the removal of hydrogen sulfide (the primary sulfur bearing compound) from hot coal gases prior to its use in combined cycle turbines. Four formulations of $\mathrm{Mn}$-based sorbents were tested in an ambient-pressure fixed-bed reactor to determine steady state $\mathrm{H}_{2} \mathrm{~S}$ concentrations, breakthrough times and effectiveness of the sorbent when subjected to cyclic sulfidation and regeneration testing. In previous reports ${ }^{16-}$ 17 , the sulfidation and regeneration results from cyclic testing done at $600{ }^{\circ} \mathrm{C}$ were presented. Manganese-based sorbents with molar ratios $>1: 1$ $\mathrm{Mn}$ :Substrate were effective in reducing the $\mathrm{H}_{2} \mathrm{~S}$ concentration in simulated coal gases to less than 100 ppmv over five cycles. Actual breakthrough time for formulation C6-2-1100 was as high as 73\% of breakthrough time based on wt\% $\mathrm{Mn}$ in sorbent. Regeneration tests determined that loaded pellets can be fully regenerated in air/steam mixture at $750^{\circ} \mathrm{C}$ with minimal sulfate formation. In this report, the results from cyclic crush strength tests, sulfur profile tests and cyclic testing at $550^{\circ} \mathrm{C}$ and lower flowrate cyclic testing are presented. Crush strength testing done after 5 cycles showed decreases in strength from $12.6 \%$ to $57.9 \%$. Cyclic testing at $550^{\circ} \mathrm{C}$ showed pre breakthrough concentrations as low as 10 ppmv. Cyclic testing done at $2 \mathrm{~L} / \mathrm{min}$ and $3 \mathrm{~L} / \mathrm{min}$ did not show any significant difference in pre breakthrough concentrations or capacity.
\end{abstract}




\section{TABLE OF CONTENTS}

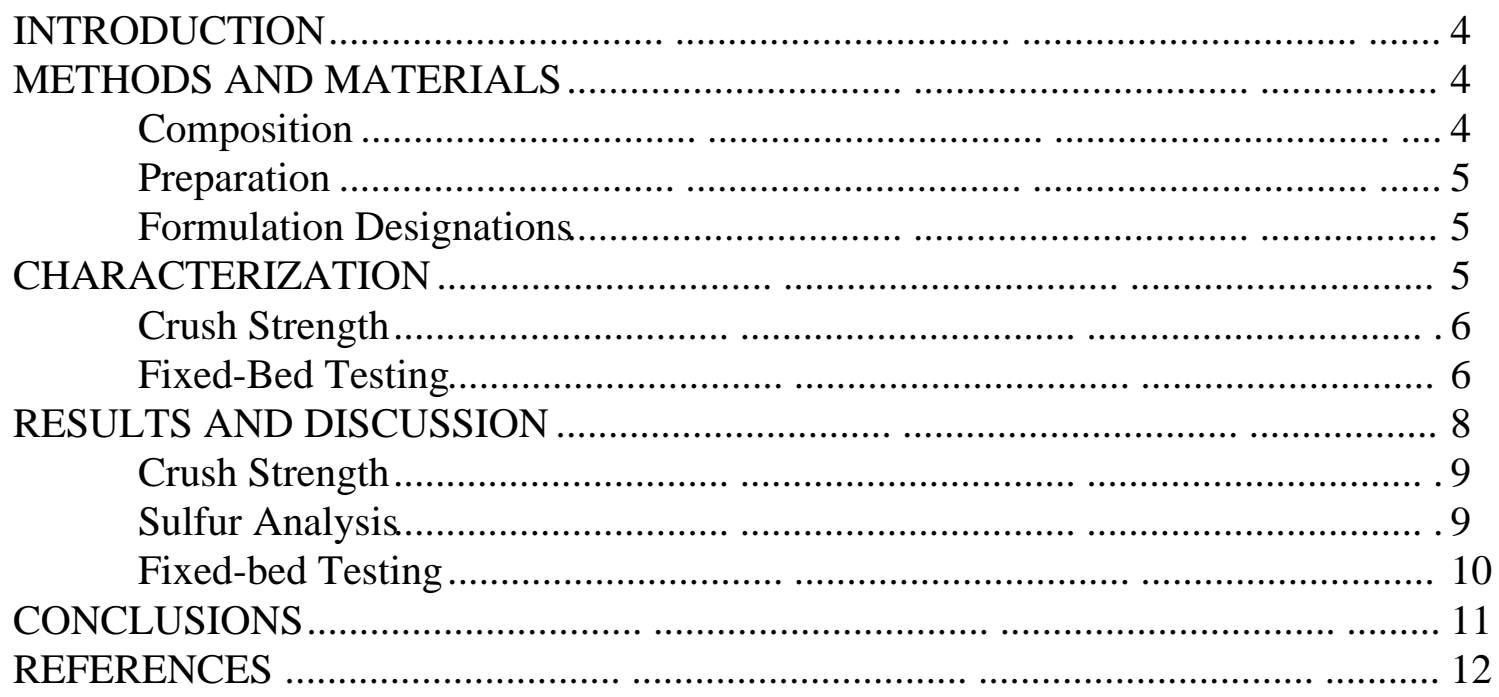




\section{INTRODUCTION}

Currently, the Morgantown Energy Technology Center, Department of Energy (DOE/METC) is actively investigating alternative hot fuel gas desulfurization sorbents for application to the Integrated Gasification Combined Cycle (IGCC) ${ }^{1}$. A sorbent must be highly active towards sulfur at high temperature and pressures, and under varying degrees of reducing atmospheres. Also, it must regenerate nearly ideally to maintain activity over numerous cycles.

Furthermore, regeneration must yield a sulfur product which is economically recoverable either directly or indirectly.

Several metal oxides have been investigated ${ }^{2-4}$ as regenerable sorbents for the removal of hydrogen sulfide (the primary sulfur bearing compound) from hot fuel gases. $\mathrm{MnO}$ was shown to have an intrinsic reaction rate approximately one order of magnitude greater than the rate or reaction with either $\mathrm{CaO}$ or $\mathrm{ZnO}$ and two orders of magnitude greater than the reaction rate with $\mathrm{V}_{2} \mathrm{O}_{3}{ }^{3}$. Manganese also shows desulfurization potential in the temperature range of $600-700^{\circ} \mathrm{C}$ where metal oxides currently known to be reactive with $\biguplus S$ are unsatisfactory?

In response to stability difficulties of single and binary metal oxide sorbents, increasing effort is being directed towards incorporation of an inert component into sorbent formulation as witnessed by the various $\mathrm{Zn}$-titanates ${ }^{5-9}$. The inert component increases pore structure integrity, stabilizes the active metal oxide against reduction and increases the pellet durability. This report will address the testing of Mn-based sorbents in an ambient pressure fixed-bed reactor. In previous reports $16-17$, the sulfidation and regeneration results from cyclic testing done at $600^{\circ} \mathrm{C}$ were presented. This report will present the results from cyclic crush strength tests, sulfur profile tests and cyclic testing at $550^{\circ} \mathrm{C}$ and lower flowrate cyclic testing.

\section{METHODS AND MATERIALS}

\section{Composition}

Variables that were considered in formulating Mn-based sorbents included:

- $\quad$ substrate composition,

- $\quad$ Mn to substrate molar ratio,

- non-volatile binder wt \%,

The only source of manganese used was from a commercially available $\mathrm{MnCO}_{3}$. Alundum and titanate were both tested as substrate based on previous considerations ${ }^{15}$. Molar ratios of $\mathrm{Mn}$ to substrate were varied from 1:1 to 4.33:1. 
Bentonite was used as a non-volatile binder at 0 and $2 \%$ by weight. All chemical compositions, vender information, and particle sizes have been reported previously 10-14.

\section{Preparation}

Feed powders were hand mixed and pelletized in a balling wheel forming "green" pellets. Green pellets were air dried for one day and then dried to a constant weight at $105^{\circ} \mathrm{C}$. Dry pellets were calcined for four hours at $350^{\circ} \mathrm{C}$. Immediately after calcination, pellets were placed in a high-temperature furnace (pre-heated to $500^{\circ} \mathrm{C}$ ), where the temperature was ramped up for 2 to 2.5 hours until final induration temperature was achieved. The pellets were indurated at this temperature for two hours. The indurated pellets were 1.2 to $2.6 \mathrm{~mm}$ in size.

\section{Formulation Designations}

Each pellet formulation can be fully described by the following designation, ex. C6-2-1100. The letter describes the manganese source ( $\mathrm{C}$ for $\left.\mathrm{MnCO}_{3}\right)$. The first number describes the substrate composition and molar ratio of $\mathrm{Mn}$ to substrate (4 for $4.33: 1 \mathrm{Mn}$ :alundum, 6 for $4.33: 1 \mathrm{Mn}$ :titania, 8 for 2:1 Mn:titania and 11 for $1: 1 \mathrm{Mn}$ :alundum. The second number is the weight percent bentonite binder. The last number is the temperature at which the pellets were indurated in degrees Centigrade. Table 1 summarizes the formulations tested in the fixedbed reactor.

\begin{tabular}{|c|c|c|c|c||}
\hline $\begin{array}{l}\text { Formulation } \\
\text { Designation }\end{array}$ & $\begin{array}{c}\text { Molar Ratio } \\
\text { Mn:Substrate }\end{array}$ & Substrate & $\begin{array}{c}\text { Wt\% } \\
\text { Bentonite }\end{array}$ & $\begin{array}{c}\text { Induration } \\
\text { Temperature } \\
\text { OC }\end{array}$ \\
\hline C4-2-1175 & $4.33: 1$ & Alundum & 2 & 1175 \\
\hline C6-2-1100 & $4.33: 1$ & Titania & 2 & 1100 \\
\hline C8-0-1200 & $2: 1$ & Titania & 0 & 1200 \\
\hline C11-0-1160 & $1: 1$ & Alundum & 0 & 1160 \\
\hline
\end{tabular}

Table 1. Formulations of Pellets Tested in the Fixed-bed Reactor and Their Designations.

\section{CHARACTERIZATION}

Indurated pellets were characterized both physically and chemically using crush strength testing, fixed-bed testing, $x$-ray diffraction (XRD) and sulfur analysis. 
Crush strength testing, sulfur analysis and fixed-bed testing will be presented in this section.

\section{Crush Strength}

The first characterization done on freshly indurated and cycled pellets was crush strength. Crush strength tests were conducted on all freshly indurated pellets with the requirement of $4.45 \mathrm{~N} / \mathrm{pellet} / \mathrm{mm}^{2}\left(1 \mathrm{lb} / \mathrm{pellet} / \mathrm{mm}^{2}\right)$ of diameter. Thus, a $1 \mathrm{~mm}$ pellet should have a crush strength of $1 \mathrm{lb} /$ pellet and a $3 \mathrm{~mm}$ pellet should have a crush strength of $9 \mathrm{lb} /$ pellet. This assumption was made previously 15 and assumes the crush strength increases proportionally with the pellet crosssectional area. Pellets were indurated at the minimum temperature required to achieve this strength. Crush strength tests were also conducted on pellets that had been sulfided and regenerated over several cycles to determine the strength retention of the pellets.

\section{Fixed-Bed Testing}

After crush testing on freshly indurated pellets proved satisfactory, they were tested in an ambient pressure fixed-bed reactor to determine steady state $\mathrm{H}_{2} \mathrm{~S}$ concentrations, breakthrough times and effectiveness of the sorbent when subjected to cyclic testing. The reactor consists of a $2.54 \mathrm{~cm}$ (1") ID quartz tube positioned vertically in the two-zone furnace. The preheat zone was maintained at $200^{\circ} \mathrm{C}$. The reaction temperature was $600^{\circ} \mathrm{C}$ and was monitored using a type $\mathrm{K}$ thermocouple positioned directly above the sorbent bed. Sulfidation and regeneration gases entered the reactor in an upward direction. Exit gases were cooled in a cold trap where vapors such as water and sulfur were condensed and collected. The gases were then scrubbed in a hypochlorous acid solution (sulfidation) or a hydrogen peroxide and sodium hydroxide solution (regeneration) prior to flaring and venting. See a previous report ${ }^{16}$ for schematics of the reactor tube and fixed-bed experimental apparatus.

For each test, 8.9 to $9.5 \mathrm{~cm}$ (40 to $55 \mathrm{~g}$ ) of sorbent was added to the reactor tube in the reaction zone. The reactor was heated in a nitrogen atmosphere to the desired operating temperature. Simulated coal gases spiked with $2.2 \mathrm{~mol} \% \mathrm{H}_{2} \mathrm{~S}$ were then introduced into the reactor at either $3 \mathrm{~L} / \mathrm{min}$ or $2 \mathrm{~L} / \mathrm{min}$. Volumetric flow rates of the gases were calibrated with rotameters using a wet test meter. Elevated $\mathrm{H}_{2} \mathrm{~S}$ concentrations were employed to reduce the sulfidation breakthrough time. Exit gases were sampled after the cold trap and were analyzed using detector tubes for $\mathrm{H}_{2} \mathrm{~S}$ until breakthrough occurred. The test conditions for sulfidation are summarized in Table 2. 


\begin{tabular}{||c|c||}
\hline Sample mass & $40-55 \mathrm{~g}$ \\
\hline Sulfidation temperature & Varied see Table 3 \\
\hline Average pellet diameter & $1.2-2.6 \mathrm{~mm}$ \\
\hline Gas composition & Shell (oxygen blown) \\
\hline Gas flow rate & Varied see Table 3 \\
\hline $\mathrm{H}_{2}$ S concentration & $2.2 \mathrm{~mol} \%$ \\
\hline Pressure & $1 \mathrm{~atm}$ \\
\hline
\end{tabular}

Table 2. Conditions of Fixed-Bed Sulfidation Experiments for all Formulations. *Refers to a simplified Shell-type fuel gas with the following composition: 64 $\mathrm{mol} \% \mathrm{CO}, 27 \% \mathrm{H}_{2}, 2.2 \% \mathrm{H}_{2} \mathrm{~S}, 2 \% \mathrm{H}_{2} \mathrm{O}, 2 \% \mathrm{CO}_{2}$ and $2.8 \% \mathrm{~N}_{2}$

\begin{tabular}{|c|c|c|}
\hline Test Designation & Temperature $\left.{ }^{\circ} \mathrm{C}\right)$ & Gas Flow Rate \\
\hline 1FB & 600 & 3 \\
\hline 2FB & 600 & 3 \\
\hline 3FB & 600 & 3 \\
\hline 4FB & 600 & 3 \\
\hline 5FB & 600 & 3 \\
\hline 6FB & 600 & 3 \\
\hline 7FB & 600 & 3 \\
\hline FB1A & 550 & 3 \\
\hline FB2A & 550 & 2 \\
\hline
\end{tabular}

Table 3. Sulfidation Gas Flow Rates and Temperatures.

The sorbent was regenerated in air, oxygen depleted air, or steam after each sulfidation test. Regeneration of the sorbent was conducted at $750^{\circ} \mathrm{C}$ and $900^{\circ} \mathrm{C}$. Regeneration in air was conducted at $900^{\circ} \mathrm{C}$. Regeneration in oxygen depleted air and air/steam mixtures was conducted at $750^{\circ} \mathrm{C}$. Five cycles of sulfidation and regeneration were conducted for tests 1FB-7FB and four cycles for tests FB1A and FB2A to determine the sorbent's activity retention. The test conditions for regeneration are summarized in Table 4 . The regeneration gas compositions and temperatures are listed in Table 5. 


\begin{tabular}{||c|c|}
\hline Sample mass & $40-55 \mathrm{~g}$ \\
\hline Regeneration temperature & $750-900^{\circ} \mathrm{C}$ \\
\hline Average pellet diameter & $1.2-2.6 \mathrm{~mm}$ \\
\hline Gas composition & Varied (see Table 4) \\
\hline Gas flow rate & $1 \mathrm{~L} / \mathrm{min}$ \\
\hline Pressure & $1 \mathrm{~atm}$ \\
\hline
\end{tabular}

Table 4. Conditions of Fixed-Bed Regeneration Experiments for all Formulations

\begin{tabular}{|c|c|c|c|}
\hline 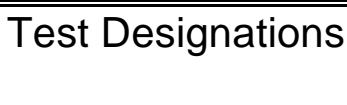 & Formulation & $\begin{array}{c}\text { Regeneration } \\
\text { Gas Composition }\end{array}$ & $\begin{array}{c}\text { Regeneration } \\
\text { Temperature }\left({ }^{\circ} \mathrm{C}\right)\end{array}$ \\
\hline $1 \mathrm{FB}$ & C6-2-1100 & $1000 \mathrm{cc} / \mathrm{min}$ air & 900 \\
\hline $2 \mathrm{FB}$ & C6-2-1100 & $\begin{array}{l}100 \mathrm{cc} / \mathrm{min} \mathrm{O}_{2} \\
900 \mathrm{cc} / \mathrm{min} \mathrm{N}_{2}\end{array}$ & 750 \\
\hline $3 F B$ & C6-2-1100 & $\begin{array}{c}50 \mathrm{cc} / \mathrm{min} \mathrm{O}_{2} \\
950 \mathrm{cc} / \mathrm{min} \mathrm{N}_{2}\end{array}$ & 750 \\
\hline $4 \mathrm{FB}$ & C6-2-1100 & $\begin{array}{c}400 \mathrm{cc} / \mathrm{min} \text { steam } \\
600 \mathrm{cc} / \mathrm{min} \text { air }\end{array}$ & 750 \\
\hline $5 \mathrm{FB}$ & C8-0-1200 & $\begin{array}{c}400 \mathrm{cc} / \mathrm{min} \text { steam } \\
600 \mathrm{cc} / \mathrm{min} \text { air }\end{array}$ & 750 \\
\hline $6 \mathrm{FB}$ & C8-0-1200 & $\begin{array}{c}800 \mathrm{cc} / \mathrm{min} \text { steam } \\
200 \mathrm{cc} / \mathrm{min} \mathrm{N}_{2}\end{array}$ & 750 \\
\hline $7 F B$ & C4-2-1175 & $\begin{array}{c}400 \mathrm{cc} / \mathrm{min} \text { steam } \\
600 \mathrm{cc} / \mathrm{min} \text { air }\end{array}$ & 750 \\
\hline FB1A & C6-2-1100 & $\begin{array}{c}500 \mathrm{cc} / \mathrm{min} \text { steam } \\
500 \mathrm{cc} / \mathrm{min} \text { air }\end{array}$ & 750 \\
\hline FB2A & C6-2-1100 & $\begin{array}{c}500 \mathrm{cc} / \mathrm{min} \text { steam } \\
500 \mathrm{cc} / \mathrm{min} \text { air }\end{array}$ & 750 \\
\hline
\end{tabular}

Table 5. Regeneration Gas Compositions and Temperatures

\section{RESULTS AND DISCUSSION}

Results from the fixed-bed sulfidation and regeneration tests 1FB-7FB were presented in previous reports $16-17$. Results from cyclic crush strength, sulfur analysis, and fixed-bed (FB1A and FB2A) testing will be presented in this section. 


\section{Crush Strength}

Results from previous reports ${ }^{16-17}$ showed that the crush strengths of freshly indurated pellets were highly sensitive to the temperature at which they were indurated. Thus in an attempt to minimize this sensitivity, the pellets were indurated for different lengths of induration. Figure 1 shows the results from the crush strength testing of freshly indurated sorbent with varying induration lengths. As can be seen in the figure, a large increase in the induration length has little impact in the crush strength. Thus very long induration lengths may be needed to minimize induration temperature effects.

Figure 2 shows the crush strengths of freshly indurated pellets and pellets after 5 sulfidation and regeneration cycles for formulations C4-2-1175 and C8-0-1200. Sorbent from test $5 \mathrm{FB}$ had the largest decrease in crush strength $(57.9 \%)$ while sorbent from test $4 \mathrm{FB}$ had only and $17.9 \%$ decrease. The sulfidation and regeneration conditions were the same (sulfidation at $600^{\circ} \mathrm{C}$ using Shell gas and regeneration at $750^{\circ} \mathrm{C}$, using a steam/air mixture), however, the sorbent formulations were different. C4-2-1175 contains 2\% bentonite binder while C80-1200 does not contain any bentonite. Sorbent from test 6FB had the smallest decrease in crush strength. This test used C8-0-1200 formulation, however, the sorbent was regenerated with a steam $/ \mathrm{N}_{2}$ mixture. These regeneration conditions does not allow for the formation of sulfates as does the steam/air mixture and may be why it had the smallest decrease in crush strength after 5 cycles.

Figure 3 shows the crush strengths of freshly indurated pellets and pellets after 4 or 5 sulfidation and regeneration cycles ( 5 cycles for 1FB-7FB and 4 cycles for FB1A and FB2A) for formulation C6-2-1100. Sorbent from test $1 F B$ had the largest decrease in crush strength. In this test, regeneration was carried out at $900^{\circ} \mathrm{C}$ using pure air. However, sorbent from tests $2 \mathrm{FB}$, and $3 \mathrm{FB}$ using oxygen depleted air had less decrease in crush strength $(21.8 \%$ and $14.6 \%$ respectively). Sorbent from test 7FB had used air/steam mixture for regeneration and had a $24.1 \%$ decrease in crush strength. Sorbent from test FB1A and FB2A had a decrease in crush strength after four cycles of $40.0 \%$ and $46.7 \%$. The difference in these two tests is the sulfidation gas flow rate $(3 \mathrm{~L} / \mathrm{min}$ and $2 \mathrm{~L} / \mathrm{min}$ ). As seen in the above results, there isn't any significant difference in the crush strength of the two sorbents after 4 cycles.

\section{Sulfur Analysis}

Figure 4 shows the sulfur profiles for sorbent from tests 1FB-7FB after the 5th regeneration. Sorbent from these tests all had approximately the same weight percent of sulfur remaining in the sorbent. Sorbent from tests $3 F B$ and $6 F B$ did, however, have slightly less weight percent of sulfur remaining. Regeneration of 
test 3FB was conducted using very oxygen depleted air $(50 \mathrm{cc} / \mathrm{min} \mathrm{O} 2$ and 950 $\mathrm{cc} / \mathrm{min} \mathrm{N2}$ ) and thus probably did not form as much sulfate as tests with regeneration in higher oxygen concentration (e.g. test 1FB).

\section{Fixed-bed Testing}

Results from the sulfidation and regeneration fixed-bed testing for tests 1FB-7FB were presented in previous quarterly reports $16-17$. Figures 5 to 9 show the results from the fixed-bed sulfidation and regeneration testing for tests FB1A and FB2A. Four cycles of sulfidation and regeneration were conducted for each test. Results from each test are described separately. A summary of the lowest pre breakthrough concentration achieved in the exit gases, breakthrough times, highest $\mathrm{SO}_{2}$ concentrations achieved in the exit gases and the time for regeneration is given in Table 6 . The theoretical breakthrough time $\left(T^{*}\right)$ was calculated based on the wt \% $\mathrm{Mn}$ in the sorbent, the $\mathrm{H}_{2} \mathrm{~S}$ concentration, the gas flow rate and equilibrium concentration as predicted by the HSC program. Actual breakthrough time was arbitrarily chosen as the time to achieve an $\mathrm{H}_{2} \mathrm{~S}$ concentration greater than $100 \mathrm{ppmv}$. Regeneration time is based on the time to achieve an exit $\mathrm{SO}_{2}$ gas concentration of less than $10 \%$ of the highest concentration achieved. The regeneration times were then average over the last three cycles.

\begin{tabular}{|c|c|c|}
\hline$\overline{~ T e s t ~ D e s i g n a t i o n ~}$ & FB1A & FB2A \\
\hline Amount of Sorbent $(\mathrm{g})$ & 47.86 & 47.88 \\
\hline Weight $\% \mathrm{Mn}$ & 55.8 & 55.8 \\
\hline Gas Flow Rate (L/min) & 3 & 2 \\
\hline $\begin{array}{c}\text { Lowest } \mathrm{H}_{2} \mathrm{~S} \text { Pre } \\
\text { breakthrough } \\
\text { Concentration (ppmv) }\end{array}$ & 10 & 10 \\
\hline $\begin{array}{c}\text { Theoretical } \\
\text { Breakthrough }\left(T^{*}, \mathrm{~min}\right)\end{array}$ & 165 & $207-302$ \\
\hline $\begin{array}{l}\text { Actual Breakthrough } \\
\text { Time }(T, \mathrm{~min})\end{array}$ & $47-72$ & NA \\
\hline$T / T^{*}$ & $0.27-0.44$ & $0.31-0.41$ \\
\hline $\begin{array}{c}\text { Highest } \mathrm{SO}_{2} \\
\text { Concentration Achieved } \\
\text { in Exit Gases (mol\%) }\end{array}$ & 6.8 & 6.4 \\
\hline $\begin{array}{l}\text { Average Regeneration } \\
\text { Time (min) }\end{array}$ & 132 & 135 \\
\hline
\end{tabular}

Table 6. $\mathrm{H}_{2} \mathrm{~S}$ Pre breakthrough Concentrations, Breakthrough Times, Highest Concentration of $\mathrm{SO}_{2}$ Achieved in Exit Gases and Average Regeneration Times. 


\section{Test FB1A}

Figure 5 is the sulfidation breakthrough plot for test FB1A. This test was conducted using simulated Shell gas at $3 \mathrm{~L} / \mathrm{min}$ for sulfidation. The lowest concentration of $\mathrm{H}_{2} \mathrm{~S}$ achieved in the exit gases was $10 \mathrm{ppmv}$, however, prior to breakthrough, the $\mathrm{H}_{2} \mathrm{~S}$ varied from 10 to $100 \mathrm{ppmv}$. The higher concentrations at the beginning of the sulfidation may be attributed to the reduction of sulfates from the previous regeneration to $\mathrm{SO}_{2}$. The initial higher concentration was not seen during the first sulfidation as it was during subsequent sulfidations. The increase in $\mathrm{H}_{2} \mathrm{~S}$ during the second sulfidation cycle at about 50 minutes may have been caused by channeling.

Figure 6 is the sulfidation breakthrough plot again for test FB1A but plotted as exit $\mathrm{H}_{2} \mathrm{~S}$ concentration versus dimensionless time (actual time/theoretical breakthrough time). This plot shows the capacity of the sorbent for each of the four sulfidation cycles. Time/T* varied from 0.27 for the first cycle to $0.38-0.44$ for subsequent cycles.

Figure 7 shows the regeneration curves for test $\mathrm{FB} 1 \mathrm{~A}$. $\mathrm{SO}_{2}$ concentrations varied from 5.5 to $6.8 \%$. These concentrations are high enough so that the exit gas may be saleable for sulfuric acid production. The average regeneration time for regeneration cycles greater than 1 was 132 minutes.

\section{Test FB2A}

Figure 8 is the sulfidation breakthrough plots for test FB2A. This test was conducted using simulated Shell gas at $2 \mathrm{~L} / \mathrm{min}$ for sulfidation. The lowest $\mathrm{H}_{2} \mathrm{~S}$ concentration achieved in the exit gases was again $10 \mathrm{ppmv}$. The ratio Time $/ \mathrm{T}^{*}$ varied from 0.30 for the first sulfidation cycle to $0.36-0.41$ for the subsequent sulfidation cycles.

Figure 9 shows the regeneration curves for test FB2A. Regeneration in $50 \%$ air and $50 \%$ steam regenerated the sorbent completely while minimizing sulfate formation and large increases in temperature. The highest $\mathrm{SO}_{2}$ concentration achieved in the exit gases was $7.4 \mathrm{~mol} \%$. The average regeneration time for regeneration cycles greater than 1 was 135 minutes.

\section{CONCLUSIONS}

The crush strength of a manganese-based pellet was highly sensitive to the temperature at which it was indurated. A large increase in the induration length had little impact in the crush strength. Thus very long induration lengths may be needed to minimize induration temperature effects. 
Crush strength testing done after 5 cycles showed decreases in strength from $12.6 \%$ to $57.9 \%$. The lowest decrease in crush strength was for sorbent regenerated in a steam $/ \mathrm{N}_{2}$ mixture. However, as shown in previous reports ${ }^{16-}$ 17 , a steam $/ \mathrm{N}_{2}$ mixture did not completely regenerate the sorbent. The largest decrease in crush strength was for a sorbent that did not contain any bentonite binder. Thus bentonite may be necessary component of the pellets.

Cyclic testing at $550^{\circ} \mathrm{C}$ showed pre breakthrough concentrations as low as 10 ppmv. Cyclic testing done at $2 \mathrm{~L} / \mathrm{min}$ and $3 \mathrm{~L} / \mathrm{min}$ did not show any significant difference in pre breakthrough concentrations or capacity.

Regeneration in $50 \%$ air and $50 \%$ steam regenerated the sorbent completely while minimizing sulfate formation and large increases in temperature. Regeneration in $50 \%$ air and $50 \%$ steam produced $\mathrm{SO}_{2}$ concentration as high as $6.8 \%$ and may be used in sulfuric acid production.

Future work will focus on the durability of the manganese pellets over many sulfidation and regeneration cycles with regeneration in an air/steam mixture.

\section{REFERENCES}

1. Ayala, R.E. et al. "Moving-Bed Sorbents", Proceedings of the Advanced Coal-Fired Power Systems '95 Review Meeting Morgantown, WV, Jun. 12-16, 1995, McDaniel et al ED. 2, pp 591-600.

2. Westmoreland, P.R. and Harrison, D.P. 1976. Evaluation of Candidate Solids for High-Temperature Desulfurization of Low-Btu Gases. Enviro. Sci. \& Tech.10(7), pp 659-661.

3. Westmoreland, P.R. et al, 1977. Comparative Kinetics of HighTemperature Desulfurization Sorbents. Enviro. Sci \& Tech.11(5), pp 488491.

4. Turkdogen, E.T. and Olsson, R.G., "Desulfurization of Hot Reducing Gases with Manganese Oxide Pellets", Proceedings of the Third International Iron and Steel Congress, Chicago, IL., Apr. 16-20, 1978, pp. 488-491.

5. Flytanzi-Stephanopoulos, M. et al. "Detailed Studies of Novel Regenerable Sorbents for High-Temperature Coal-Gas Desulfurization" I. Proceedings of the Sixth Annual Meeting on Contaminant Control in Coal-Derived Gas Streams, 1986: DOE/METC-86/6042.

6. Gangwal, S.K., et al, 1989. Bench-Scale Testing of High-Temperature Desulfurization Sorbents, Environmental Progress, 8(4), pp 265-269. 
7. Woods, M.C., et al 1990. Reaction between $\mathrm{H}_{2} \mathrm{~S}$ and Zinc Oxide-Titanium Oxide Sorbents. 1. Single-Pellet Kinetic Studies, Ind. Eng. Chem. Res., 29(7), pp 1160-1167.

8. Mojtahedi, W. et al, 1994. Desulfurization of hot coal gas in fluidized bed with regenerable zinc titanate sorbents, Fuel Processing Technology, 37, pp 53-65.

9. Focht, G.D. et al. "Structural Property Changes in Metal Oxide Hot Coal Gas Desulfurization Sorbents" Final Report July 1986. DOE/MC/21162163.

10. Hepworth, M.T. "Kinetics of Mn-Based Sorbents for Hot Coal Gas Desulfurization" Quarterly Report for the period of December 15, 1994 to March 15, DE-GG-22-94PC94212, 1995.

11. Hepworth, M.T. "Kinetics of Mn-Based Sorbents for Hot Coal Gas Desulfurization" Quarterly Report for the period of March 15 to July 15, DE-GG-22-94PC94212, 1995.

12. Hepworth, M.T. "Kinetics of Mn-Based Sorbents for Hot Coal Gas Desulfurization" Quarterly Report for the period of July 15 to September 15, DE-GG-22-94PC94212, 1995.

13. Hepworth, M.T. "Kinetics of Mn-Based Sorbents for Hot Coal Gas Desulfurization" Quarterly Report for the period of September 15 to December 15. DE-GG-22-94PC94212, 1995.

14. Hepworth, M.T. "Kinetics of Mn-Based Sorbents for Hot Coal Gas Desulfurization" Quarterly Report for the period of December 15, 1995 to March 15, DE-GG-22-94PC94212, 1996.

15. Hepworth, M.T. "Kinetics of Mn-Based Sorbents for Hot Coal Gas Desulfurization" Quarterly Report for the period of March 15 to June 15, DE-GG-22-94PC94212, 1996.

16. Hepworth, M.T. "Kinetics of Mn-Based Sorbents for Hot Coal Gas Desulfurization" Quarterly Report for the period of June 15 to September 15, DE-GG-22-94PC94212, 1996.

17. Hepworth, M.T. "Kinetics of Mn-Based Sorbents for Hot Coal Gas Desulfurization" Quarterly Report for the period of September 15 toMarch 15, DE-GG-22-94PC94212, 1996. 


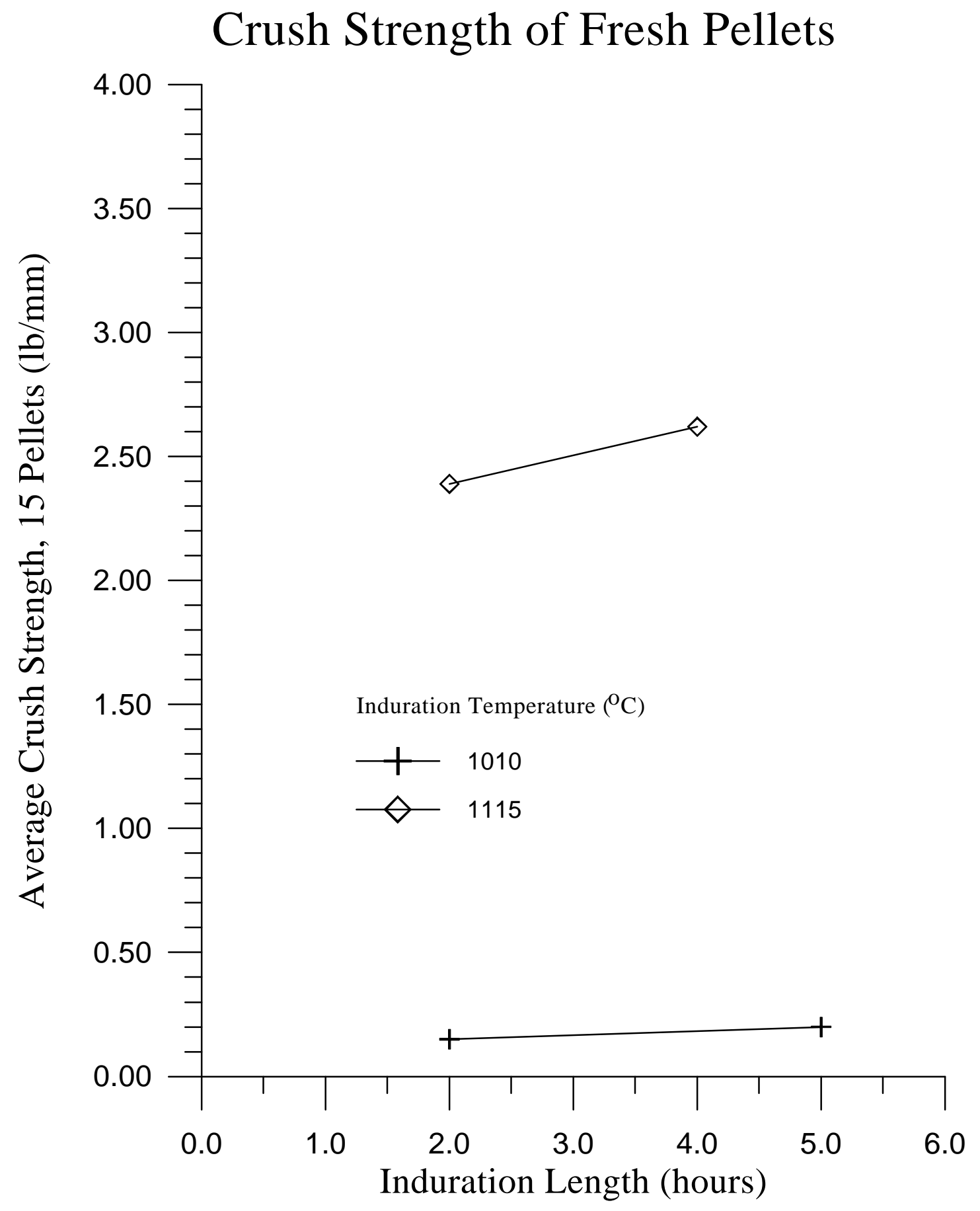

Figure 1. Average Crush Strength for fresh C6-2 pellets, $1.30-2.30 \mathrm{~mm}$ in diameter 


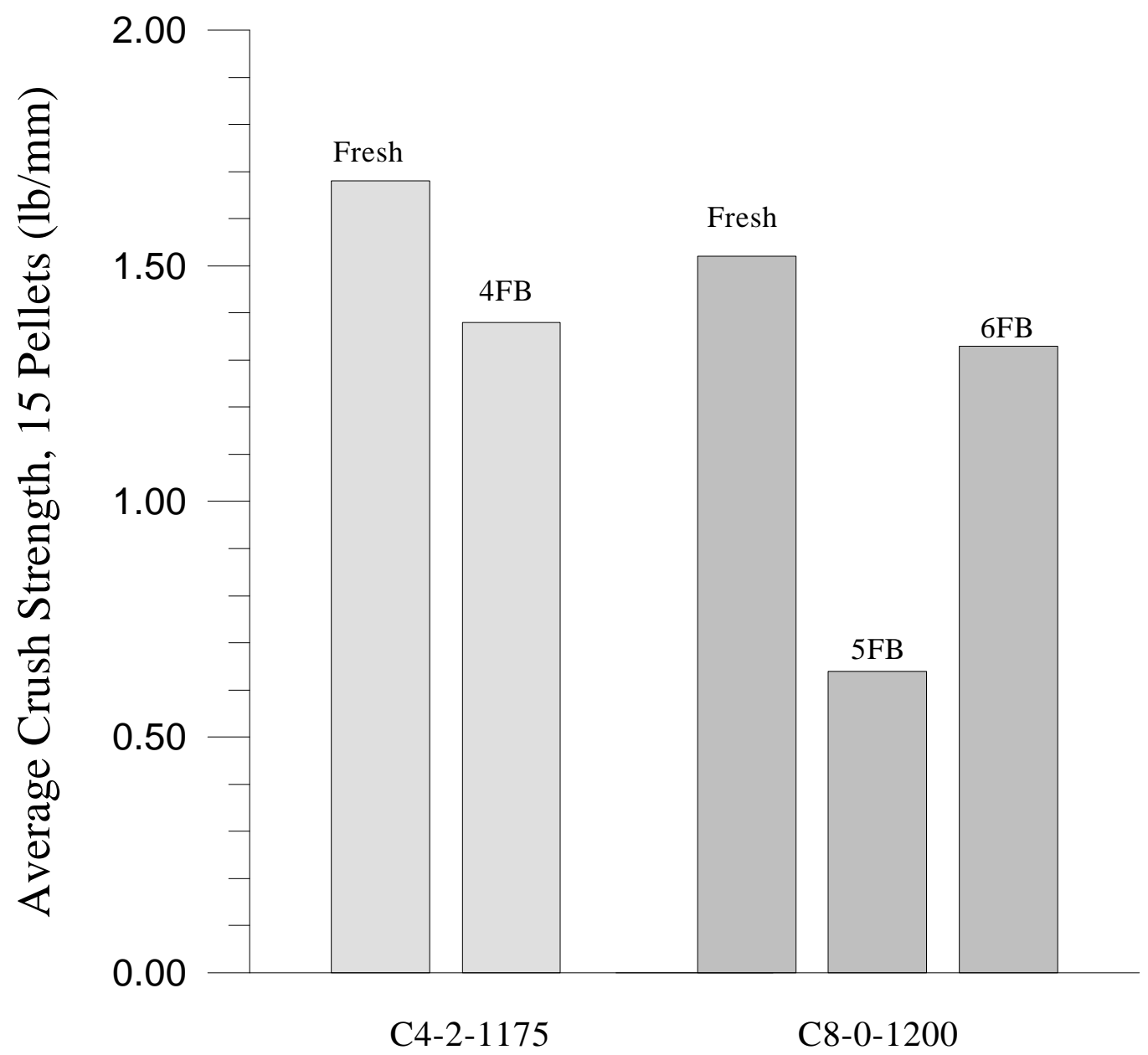

Figure 2. Average crush strength of fresh pellets and pellets after 5 cycles in fixed bed 


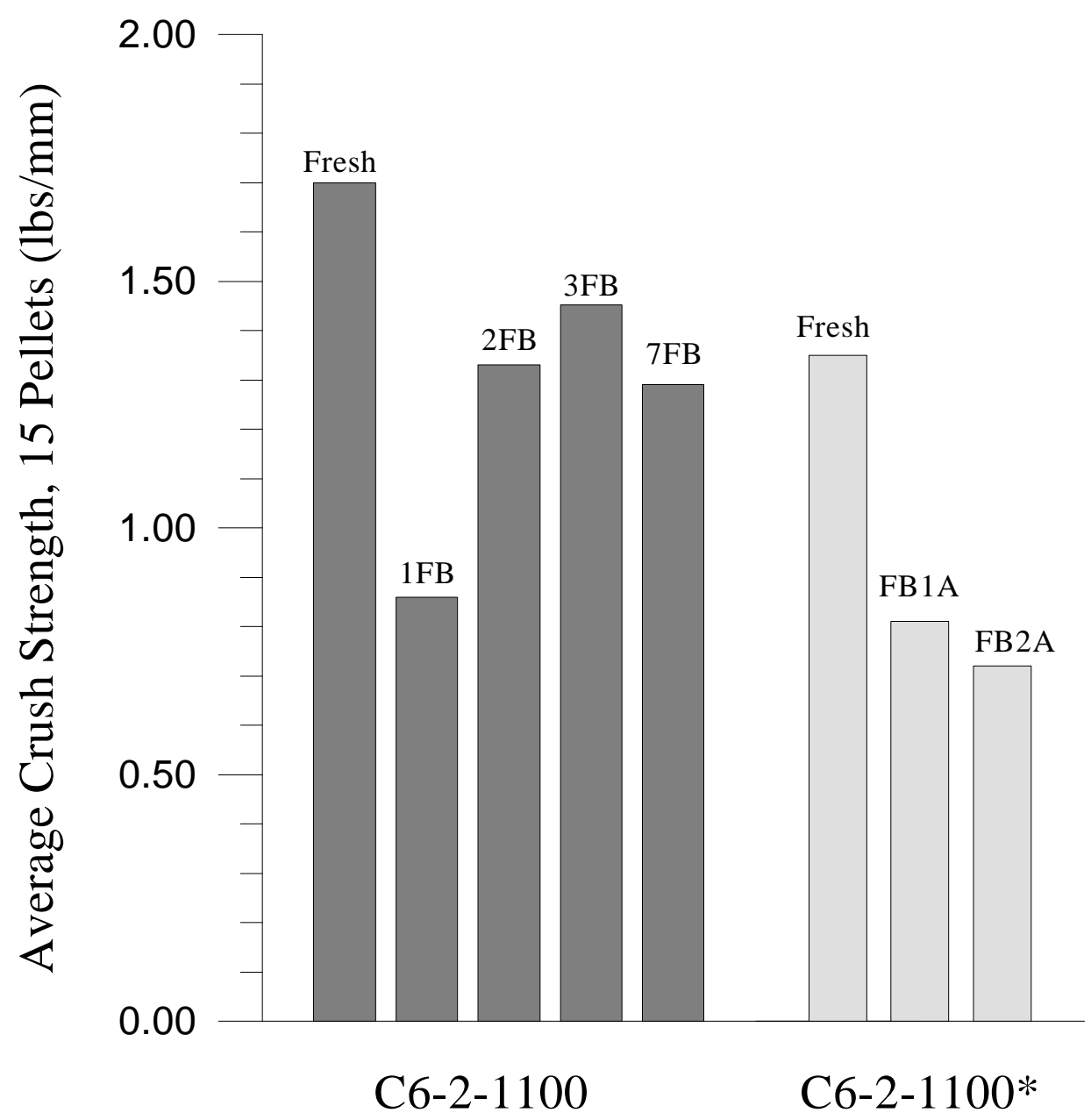

Figure 3. Average Crush Strength for C6-2-1100 formulations fresh and after 5 cycles in fixed bed *A second batch of C6-2-1100 was prepared with slightly different fresh strength, 4 cycles 


\section{Sulfur Profiles}

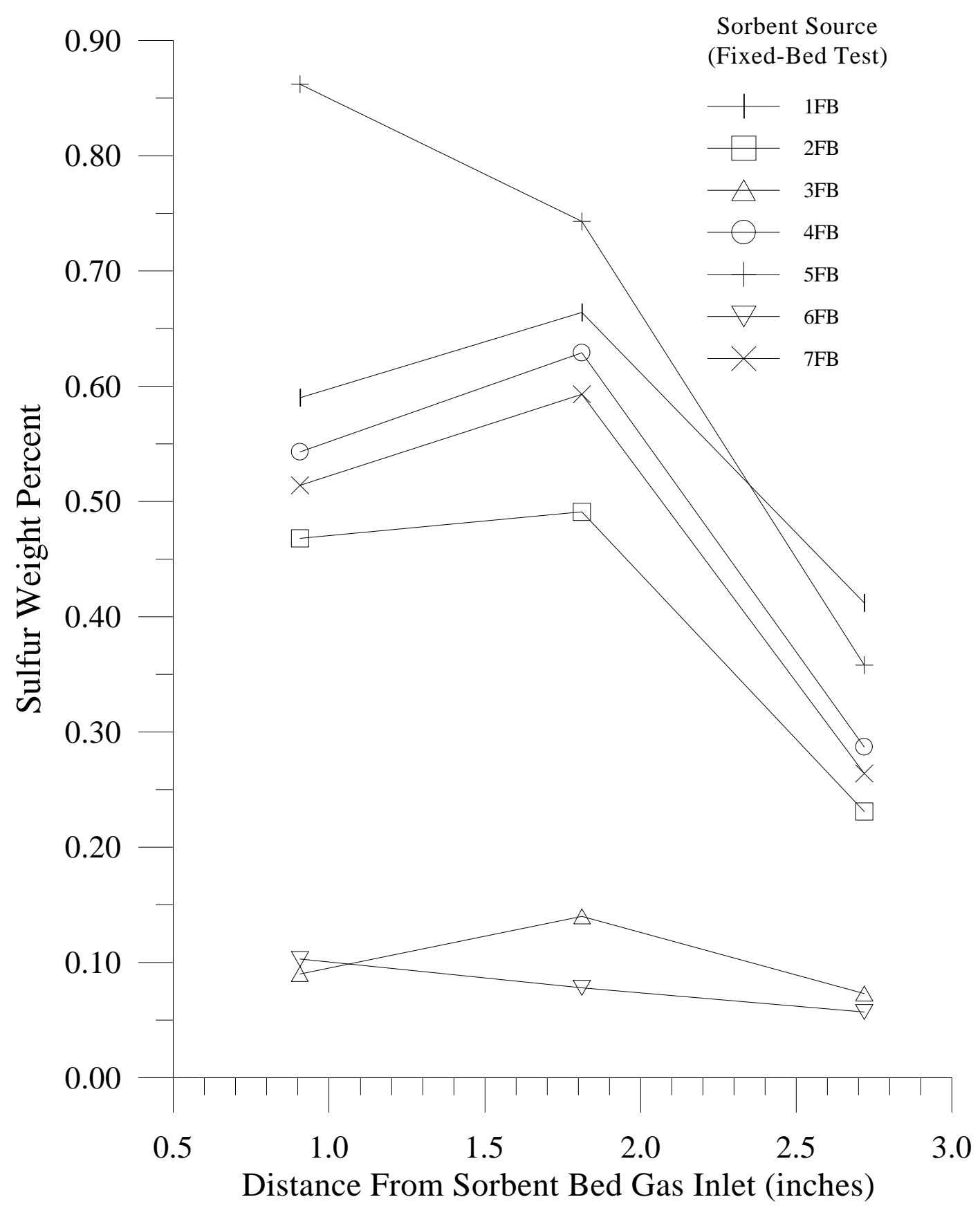

Figure 4. Sulfur Weight percent in sorbent after 5 cycles in fixed bed 

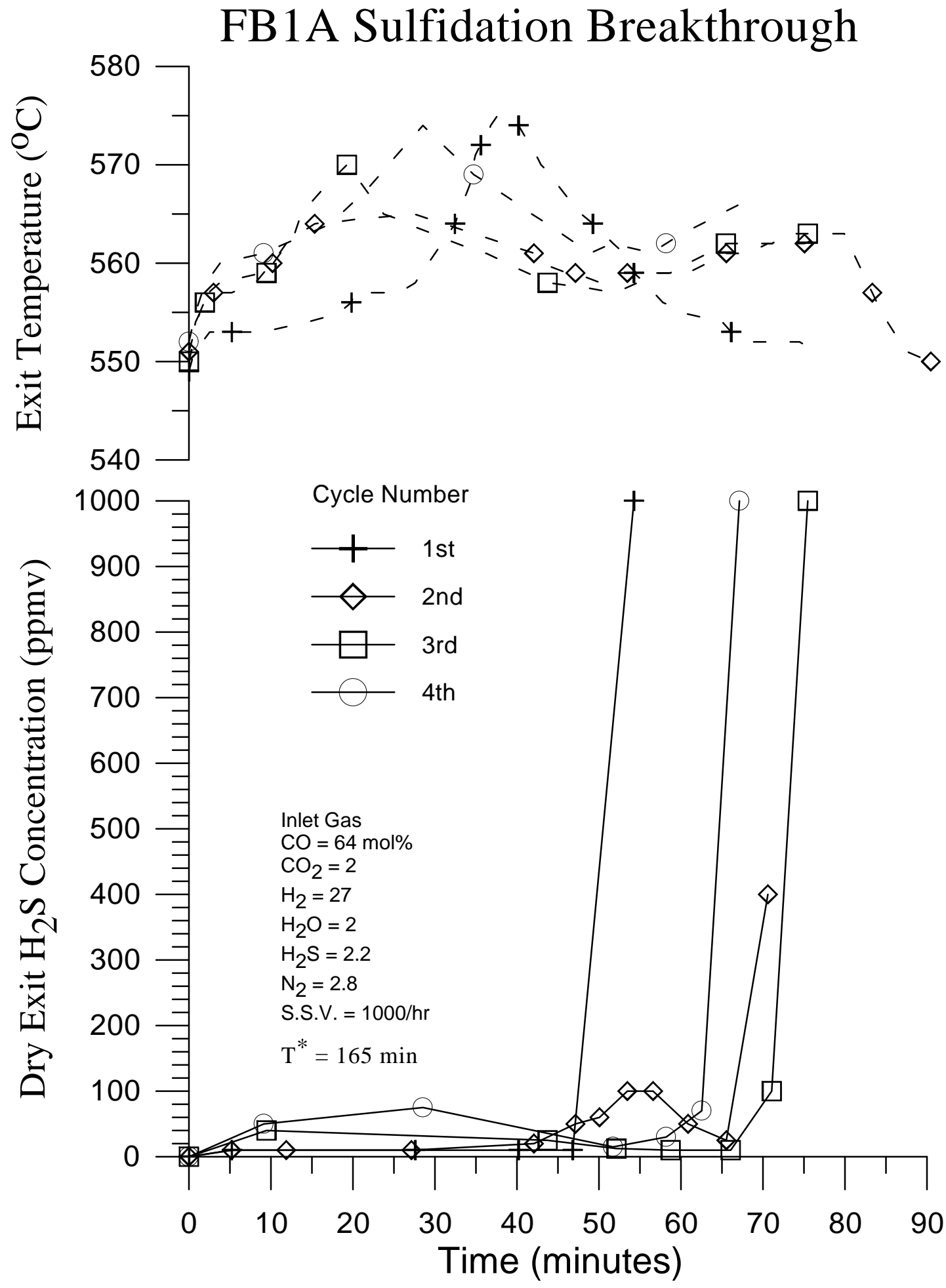

Figure 5. FB1A sulfidation breakthrough curves for C6-2-1100, with regeneration in 50 mol\% air and $50 \% \mathrm{H}_{2} \mathrm{O}$, at $750^{\circ} \mathrm{C}$. $\mathrm{T}^{*}$ is the theoretical time to breakthrough. 


\section{FB1A Sulfidation Breakthrough at $550^{\circ} \mathrm{C}$}

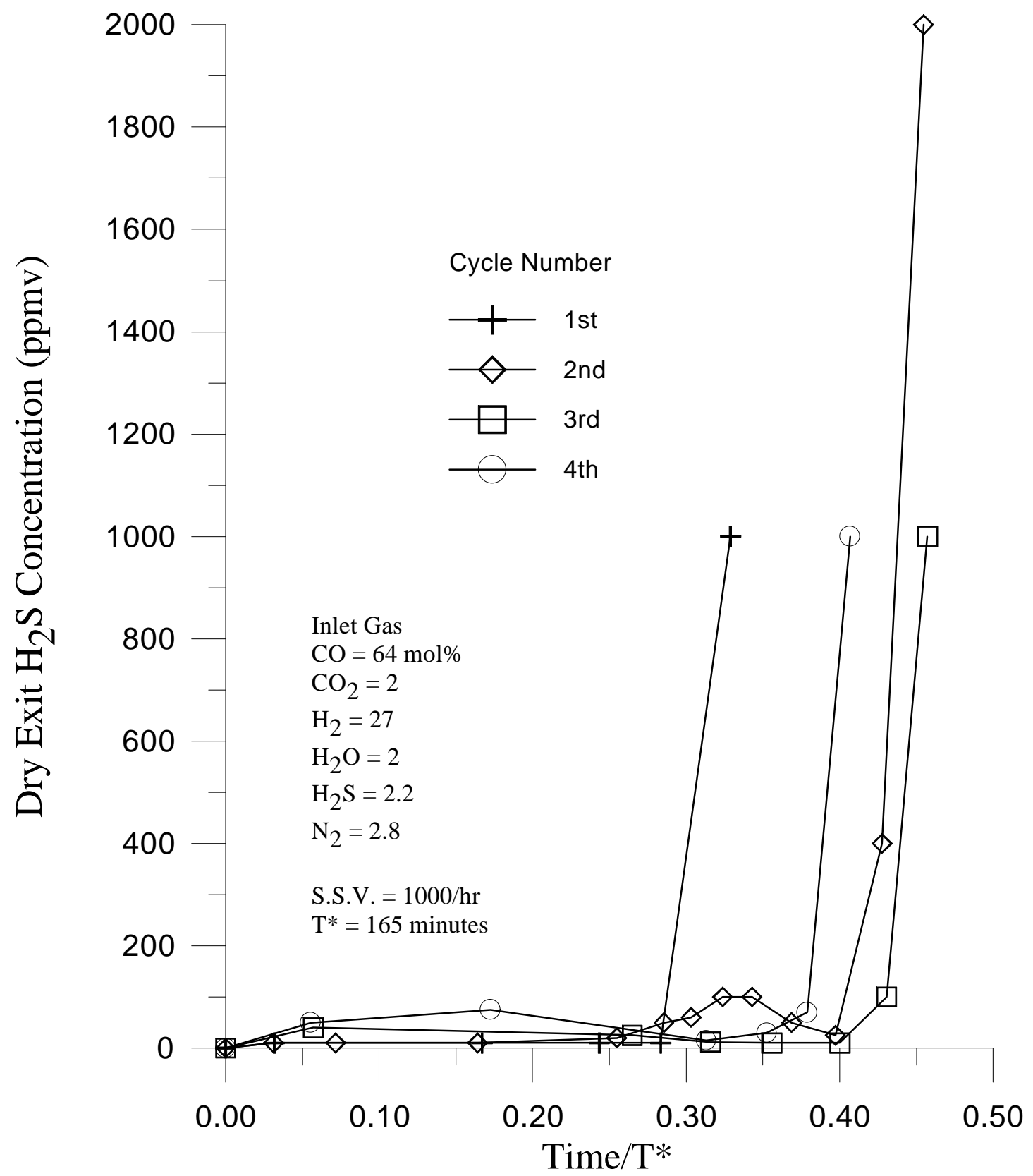

Figure 6. FB1A sulfidation breakthrough curves for C6-2-1100, plotted as $\mathrm{H}_{2} \mathrm{~S}$ concentration versus dimensionless time. $\mathrm{T}^{*}$ is the theoretical time to breakthrough. 


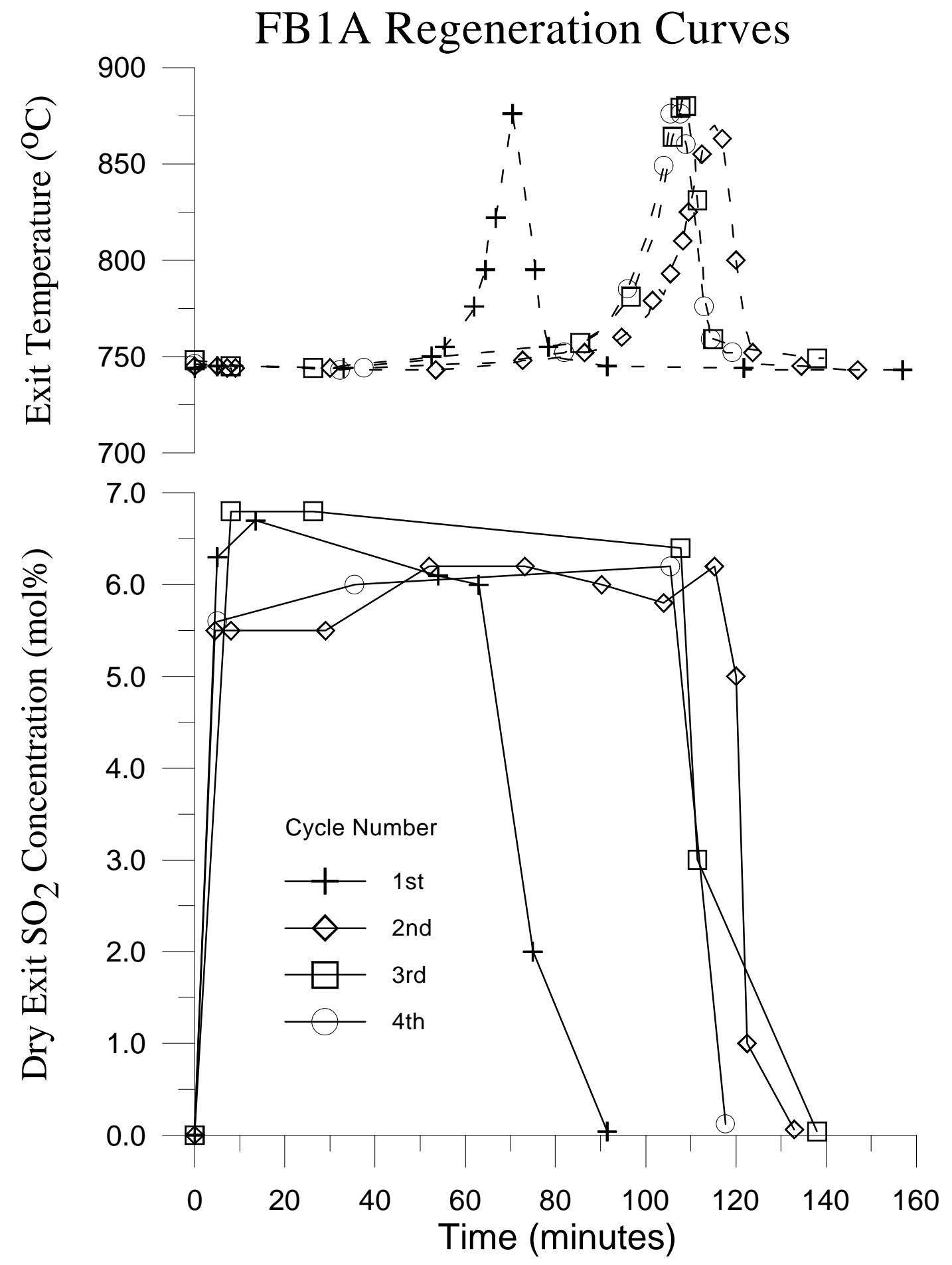

Figure 7. FB1A regeneration curves for C6-2-1100. Regeneration in $50 \mathrm{~mol} \%$ air and $50 \% \mathrm{H}_{2} \mathrm{O}$, with a standard space velocity of $333 / \mathrm{hr}$. 


\section{FB2A Sulfidation Breakthrough at $550^{\circ} \mathrm{C}$}

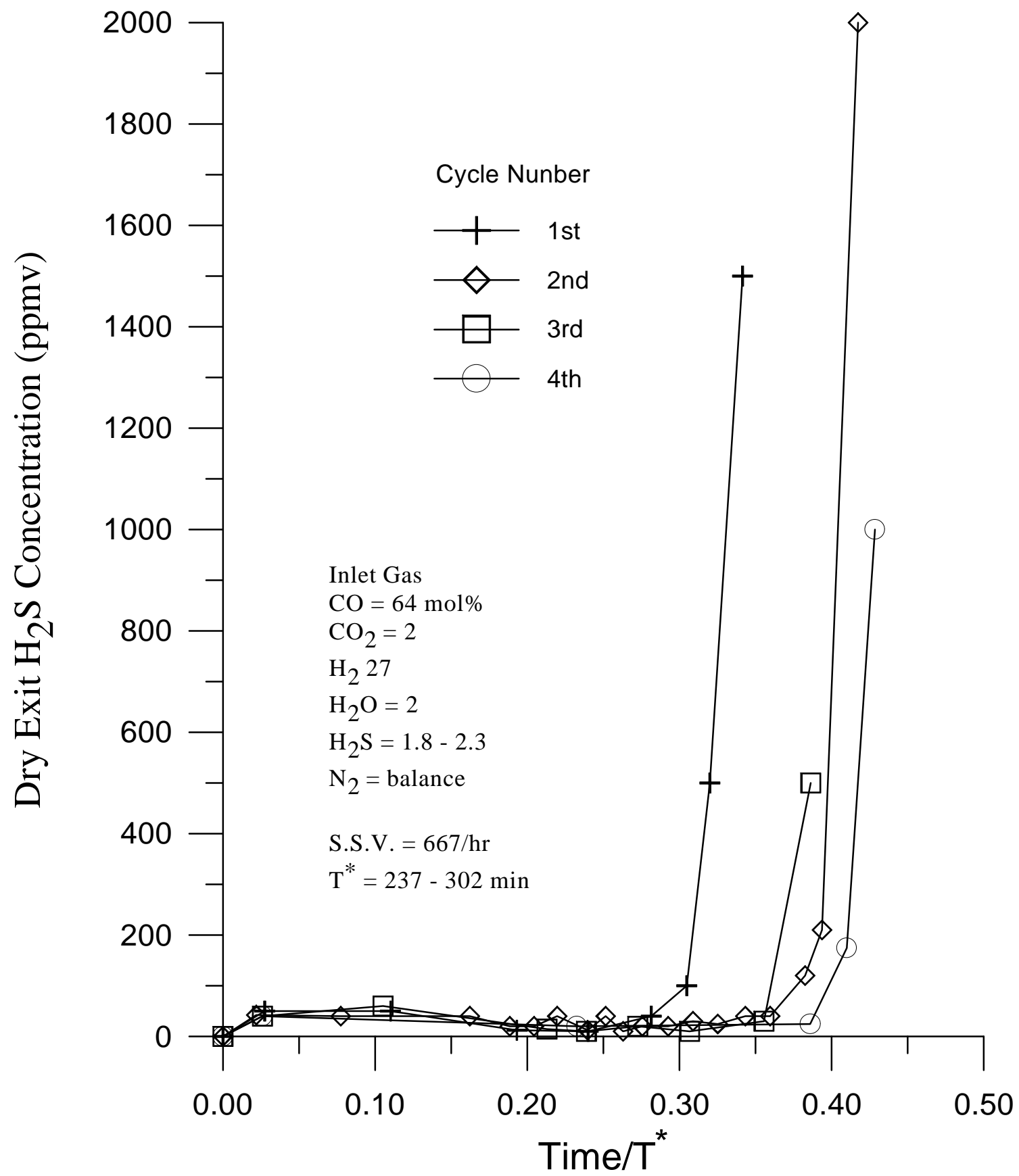

Figure 8. FB2A sulfidation breakthrough curves for C6-2-1100, with regeneration in 50 mol\% air and $50 \% \mathrm{H}_{2} \mathrm{O}$, at $750^{\circ} \mathrm{C}$. $\mathrm{T}^{*}$ is the theoretical time to breakthrough. 


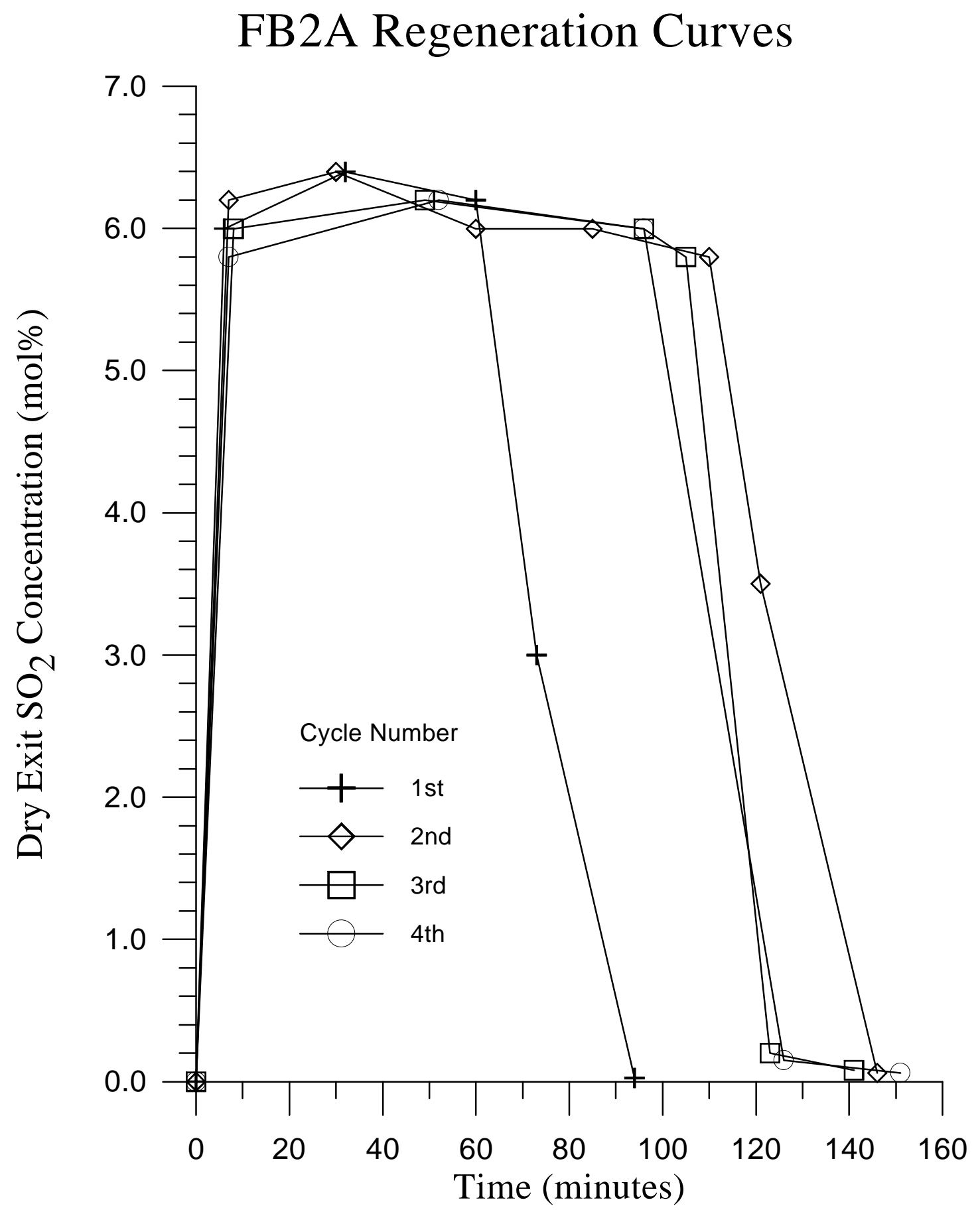

Figure 9. FB2A regeneration curves for C6-2-1100. Regeneration in 50 mol\% air and $50 \% \mathrm{H}_{2} \mathrm{O}$, with a standard space velocity of $333 / \mathrm{hr}$, at $750^{\circ} \mathrm{C}$. 